\title{
油脂変敗と食飭の栄養効率（第 1 報） \\ Effect of the Rancidity of Oils on the Nutritive Efficiency of Food (Part 1)
}

\author{
加熱大豆油の変敗度と消化率 \\ Effect of Heating on the Alteration of the Properties and Enzyme \\ Digestibility of Soybean Oil \\ 生 活 学 園 短 期 大 学 \\ (Seikatsu Gakuen Junior College) \\ 細川和子 (K. Hosokawa) \\ 埼玉 大学教 育学部 \\ (Saitama Univercity, Department of Education)
}

小川喜美江 (K. Ogawa) 和田冨起 (F. Wada)

Two kinds of the oxidation condition, in open air at $180^{\circ} \mathrm{C}$ and 80 to $90^{\circ} \mathrm{C}$ with air bubbling, on the digestion in vitro of soybean oil by pancreatic lipase were studied, and whether the properties, which are acid value, peroxide value, iodine number, viscosity, and refractive index, have close connection with the digestibility was also examined.

The properties of the oil were altered during the two oxidation conditions. In vitro digestion of the oil which oxidized in open air at $180^{\circ} \mathrm{C}$ decreased markedly with increasing viscosity. Peroxide value increased in duration of oxidation with air bubbling at 80 to $90^{\circ} \mathrm{C}$ accompanied with decreased digestibility of the oxidized oils. Though peroxide value decreased when the oils of high peroxide value boiled at $180^{\circ} \mathrm{C}$, the in vitro digestion of that oils was not improved.

変敗した油脂を投与すると, 幼動物の生長が阻害されることは, 多数の人が観察している。その原因の一つ は，油自体の栄養効率の低下によるべきは勿論であるが，他方この種の油脂を含む食餌全体の栄養効率の低下 という点も見逃し難いところである。本報では，種々の条件下で変敗を起こした大豆油のみにつき，その一部 を大約消化率の観点から捉えて見た。

われわれの日常生活における揚げ物用の油は, 同一品を繰り返し加熱利用することが多い。また近来は油脂 の摂取量を多くする一法として，炒め料理もよく普及して来たが，この際には古い油を利用することが少なく ない。この種の油は, 普通腰が弱くなり, 幾分渋酸味を有し, 黒色で, ドロドロの物もある。ともかく, 程度 の差こそあれ変敗した油脂である。この種の油の食用効率を咞う一端として, 加熱変敗油の消化率を人工消化 法により新鮮な油のそれと比較検討した。

油性として, 酸価・過酸化物価・沃素価・屈折率・粘度などを測定し, 試料油の変質の度合を推定した。 
油の人工分解度測定条件は, 赤堀法 ${ }^{1}$ 飞準じて予備実験の結果, 次の通りに定め, 対照油となる新鮮素材油 (大豆油) の分解程度 (約 $24 \%$ ) 100 として, その比消化率を以って比較した。
(1) 基質量 試料油 $2.5 \mathrm{~g}$
(2) 酵素量 市販リパーゼ $80 \mathrm{mg}$
(3) 水素イオン濃度 $\mathrm{pH} 9.0$ (アンモニア緩衝液)
(4) 反応温度 $39^{\circ} \mathrm{C}$
(5) 反応時間 120 分
(I) 高温 $\left(180^{\circ} \mathrm{C}\right)$ 加熱油について
(1) 試料油の調製

素材生大豆油を $180^{\circ} \mathrm{C}$ に加熱する。 $180^{\circ} \mathrm{C}$ 保持時間は，1，10，30，50時間の 4 種とし，それぞれの加熱 (重合) 油と素材生大豆油各 $50 \mathrm{~g}$ 学褐色嚗にとり, N死斯を封じ込み, 冷暗所に保存し, 本実験の試料とす る。

(2) 油性測定

以上の各試料につき, 常法: により油性を測定し, 第 1 表に示す結果を得た。

第 1 表 加熱 (重合) 油の油性

\begin{tabular}{|c|c|c|c|c|c|c|}
\hline 料 & 酸 & 過酸化物 価 & 屈 & 率 & 比 & 粘 \\
\hline 生 大豆 油 & 0.041 & 0.42 & & 1. 4719 & & 36.7 \\
\hline 1 時間加熱油 & 0.067 & 8.45 & & 1.4720 & & 36.0 \\
\hline $10 \quad \prime$ & 0.222 & 15.10 & & 1. 4731 & & 48.5 \\
\hline 30 & 0.756 & 11.72 & & 1.4745 & & 91.9 \\
\hline 50 & 1. 013 & 11.09 & & 1.4745 & & 184.6 \\
\hline
\end{tabular}

イ) 酸価の変動：酸価は加熱時間と共に徐々に上昇し，50時間で 第 1 図 は初めの酸価の約 25 倍となるが,その実測值の幅は甚だ小さい。

口) 過酸化物価の変動 : 過酸化物価は加熱により初め急に上昇 し，1時間加熱により約20倍となり，その後も上昇を続け，10時間 加熱したものでは, 初めの約50倍になる。ただしその絶対值は小さ い。しかして, 10時間加熱の前後を最高として低下しはじめ, 加熱 30時間においては, 正対照油の30倍以下となり，その後は変化しな w。

八）屈折率：属折率は第 1 表に示す如く殆えど数值の上に変化は 認的られなかった。

二) 比粘度（第 1 図）：比粘度は 1 時間加熱により, 僅かに低下 するが，その後少しずつ上昇の傾向を示し，10時間加熱により生大 豆油の約 1.3 倍, 30時間では約 2.5 倍となり,さらに50時間では生大 豆油のそれの約 5 倍になる (第 1 図)。すなわ方比粘度は長時閒加 熱により相当に上昇することが知られる。

（3）人工消化率：以上の 5 試料につき, 既定の条件に従って分解

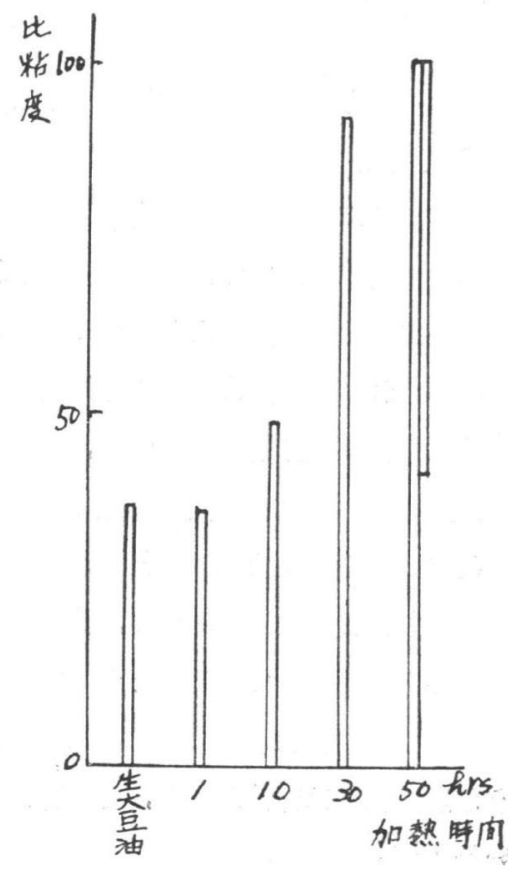


第 2 表 加熱 (重合) 油の消化率

\begin{tabular}{|c|c|c|}
\hline 試 & 分解度 & 比消化率 \\
\hline 生 大豆 油 & 24.6 & 100 \\
\hline 1 時間加熱油 & 28.0 & 114.3 \\
\hline $10 \quad \prime$ & 20.9 & 84.9 \\
\hline 30 & 15.7 & 64.1 \\
\hline $50 \quad \prime \prime$ & 12.3 & 50.2 \\
\hline
\end{tabular}

度を測定し，その比消化率を算出した。その結果を第 2 表に掲げ る。表に明らかなように, 生大豆油のそれよりも，1時間加熱し たものは分解度が多少高い。しかしその後は加熱時間の長びくと 共に次第に分解度は低下し，50時間加熱油の分解度は生大豆油の それの約 $1 / 2$ となるすなわ方過熱により消化率が著しく低下する ことを知る。

この消化率の低下傾向と, 何れの油性の変化が最も相関するか索観察すると, 比粘度の上昇に伴い, 分解度 すなわち比消化率が低下してゆくことが知られる(第 2 図)。

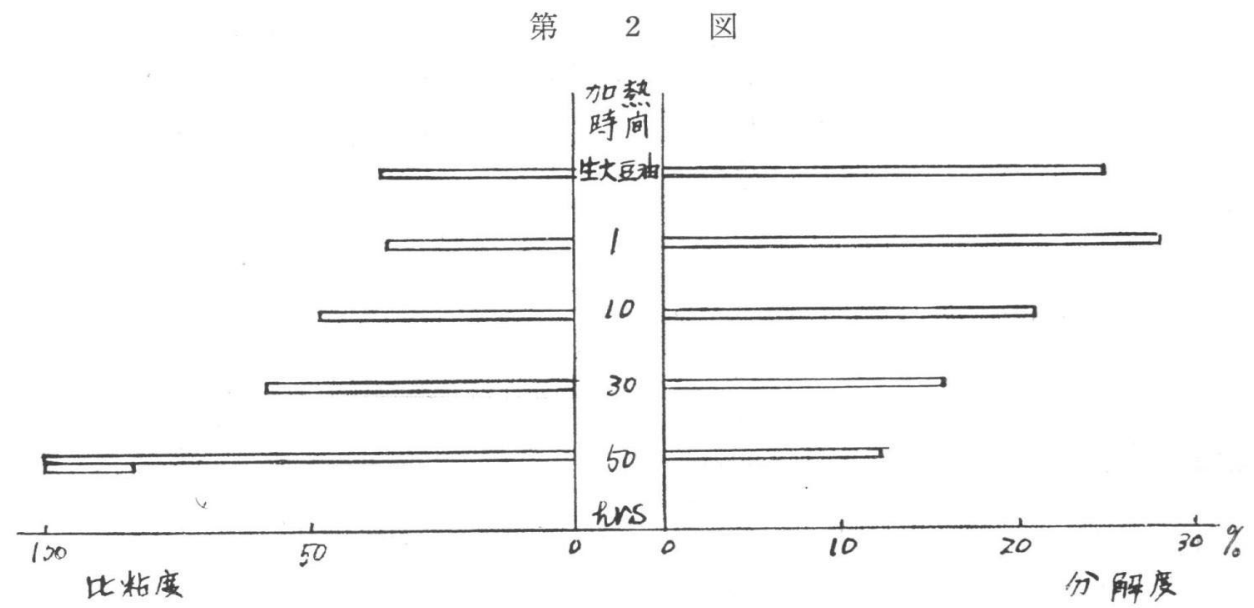

この図によれば，比粘度と分解度は相関が高い感があるが，その相関は必ずしも linear ではない。従って 他の油性もまた比消化率低下に影響しているととを暗示しているものと思われる。

(4) 要 約

生大豆油を素材とし， $180^{\circ} \mathrm{C}$ に加熱する。 $180^{\circ} \mathrm{C}$ 加熱保持時間は $1 ， 10,30,50$ 時間である。これらの油の 油性の変化とそれぞれの人工消化率との関係につき要約する。

1）過酸化物価・酸価は, $180^{\circ} \mathrm{C}$ 加熱によりある程度上昇するが，変動は小さい。なお，過酸化物価吅熱 時間が長くなると下がる傾向にある。

2）屈折率においては変化は認められない。

3）比粘度は加熱により著しく変化し，加熱時間が延長するに従って，その粘度は相当に大となる。

4) これらの加熱大豆油の分解度 (比消化率) は，加熱時間の延長するに伴い，下降の傾向定示す。

5）加熱油の分解度の変動は, 油の粘度の変化と最も密接な関係を示す。

以上の如く, 長時間高温加熱に伴い, 油の分解率 (比消化率) が目立って低くなることを知った。

\section{(II) 高過酸化物価油の比消化率}

私たちは日常生活において, 油の調理として揚物を良くするが, 同じ油を何回も使用したり，その残った油 をそのまま放置していることが多い。しかし油脂, 特に不飽和脂肪酸の多い油は, 自動酸化を受け易く, 酸化 によって過酸化物を生成する。過酸化物の生成は, 温度が低く誘導期間が長い程, その最高量は高い。このよ うな過酸化物は毒性があり, その毒性は含有する過酸化物量に平行し, 蛋白質をも毒性化せしめると言われて (る3) ${ }^{3) 51}$ 。 
このような過酸化物の多い油は, 消化率においても影響を受けていると思われる。そこで特に可及的に過酸 化物価の高い油を作り，その人工消化率を比較した。

(1) 実験素材

市販品 1 斗缶入り大豆油を用いた。

(2) 試料油の調製

素材生大豆油に空気を吹き込みながら所定時間 $80^{\circ} \sim 90^{\circ} \mathrm{C}$ に加熱保持し, 次の試料 $\mathrm{A} \cdot \mathrm{B} \cdot \mathrm{C}$ 它得た。試料油 の過酸化物価は, 試料 A 約 100 , 試料 B 約 200 , 試料C 約 400 である。加熱時間と空気吹込量を第 3 表に示す。

第 3 表＼cjkstart高過酸化物価油の調製

\begin{tabular}{|c|c|c|c|}
\hline 試料油 & 過 酸 化 物 価 & 加熱通気時間 & 空気吹込量 $l$ \\
\hline A & 103.02 & $37: 30$ & 4494.5 \\
B & 230.60 & $45: 30$ & 5873.8 \\
C & 399.60 & $76: 30$ & 9876.5 \\
\hline
\end{tabular}

(3) 実験種類

素材生大豆油および試料油の油性（過酸 化物価・酸価・屈折率・比粘度）と分解度 を前述の方法で測定した。

(4) 実験結果と考察

A、試料油の油性 (第 4 表)

1) 過酸化物価は加熱通気時間の経過と共に上昇する。酸価も加熱通気時間の経過と共に上昇する。しかし この操作においてはそれぞれの上昇の度は平行せず, 過酸化物価は急激に且つ高度の上昇を示すが, 酸価の上 昇は極めて低い。

第 4 表 試 料 油 $の$ 油 性

\begin{tabular}{|c|c|c|c|c|c|c|c|c|c|c|}
\hline 試 料 & 加熱通気時間 & 過 酸化物 価 & 酸 & 価 & 屈 & 折 & 率 & 比 & 粘 & 度 \\
\hline 生大豆油 & $\begin{array}{r}\text { 時間 } \quad \text { 分 } \\
\quad 0\end{array}$ & 0.42 & & & & 1. 47 & & & 36.7 & \\
\hline A & $37: 30$ & 103. 02 & & & & 1.47 & & & 37.3 & \\
\hline B & $45: 30$ & 230.60 & & & & 1.47 & & & 46.0 & \\
\hline $\mathrm{C}$ & $76: 30$ & 399.60 & & & & 1.47 & & & 59.5 & \\
\hline
\end{tabular}

2）過酸化物価は約 37 時間の加熱通気により約 $100 に ，$ 加熱通気約 45 時間に及べば，約 230 となり，76時間で は約 400 に達している。すなわち初めの 37 時間の上昇率よりも次いで来る $7 \sim 8$ 時間の上昇率は著しく大で， 初らの約 37 時間の加熱通気による上昇率注平均毎時 3 弱であるのに対して, 次いで来る 8 時間の過酸化物価上 昇率は毎時16を示す。次いで来る約20時間のそれは毎時 8 強であって, この加熱通気条件では37時間と45時間 の間 (約40時間位) の時が上昇率が最大になっている。

以上に見られる如く, $80^{\circ} \sim 90^{\circ} \mathrm{C}$ の低温加熱においては通気穵行なっても酸価の上昇は極めて小であるのに 比し，過酸化物価の上昇は極めて急激で且つ高度であった。

3）これらの試料油の屈折率は正対照のそれと何らの差を示さなかった。

4）比粘度は低温加熱通気で洔間の経過と共に多少高くなるが高温加熱の場合よりその差は極めて小さく， 操作76時間で，比粘度は $60 \%$ 強を増加しているのみである。

以上に見る如くこの試料油は, 過酸化物価のみが高く $(100,200,400)$, 比粘度が多少上昇し酸価・屈折率 注生大豆油のそれとあまり変化を示さないというものである。

\section{B. 試料油の分解度}

これらの油の分解度を測定し，過酸化物価との関係を知るために次の実験を行なった。前述の実験条件の許 に分解度の測定を行なう。結果を第 5 表に示す。（なお本表には分解度に関係すると思われる油性および比消 
第 5 表 油性と比消 化 率

\begin{tabular}{|c|c|c|c|c|c|c|c|c|}
\hline 試 料 & 加熱通気時間 & 過酸化物 価 & 比 & 粘 & 度 & 分 & 解 度 \% & 比 消 化 率 \\
\hline 生大豆油 & $\begin{array}{l}\text { 時間 分 } \\
0\end{array}$ & 0.42 & & 36.7 & & & 24.6 & 100 \\
\hline A & $37: 30$ & 103.02 & & 37.3 & & & 20.8 & 84,4 \\
\hline B & $45: 30$ & 230.60 & & 46.0 & & & 11.4 & 46.4 \\
\hline $\mathrm{C}$ & $76: 30$ & 399.30 & & 59.5 & & & 10.4 & 42.4 \\
\hline
\end{tabular}

化率を併記した。)

表に示す如く, 生大豆油の分解度 $24 \%$ に比して, A油(過酸化物価約100)は分解度 $20.8 \%$ 之低くなっている。 次のB油（過酸化物価約200）の分解度は $11.4 \%$ と生大豆油の $1 / 2$ に満たない值を示し，消化が非常に悪くな

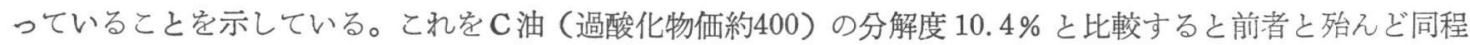
度の分解度を示している。すなわち過酸化物価が約 200 位までは, その高くなるのに伴い分解度が低くなるこ とおよびこの分解度が最低限度であることを示していると考えられる。

第 3 図

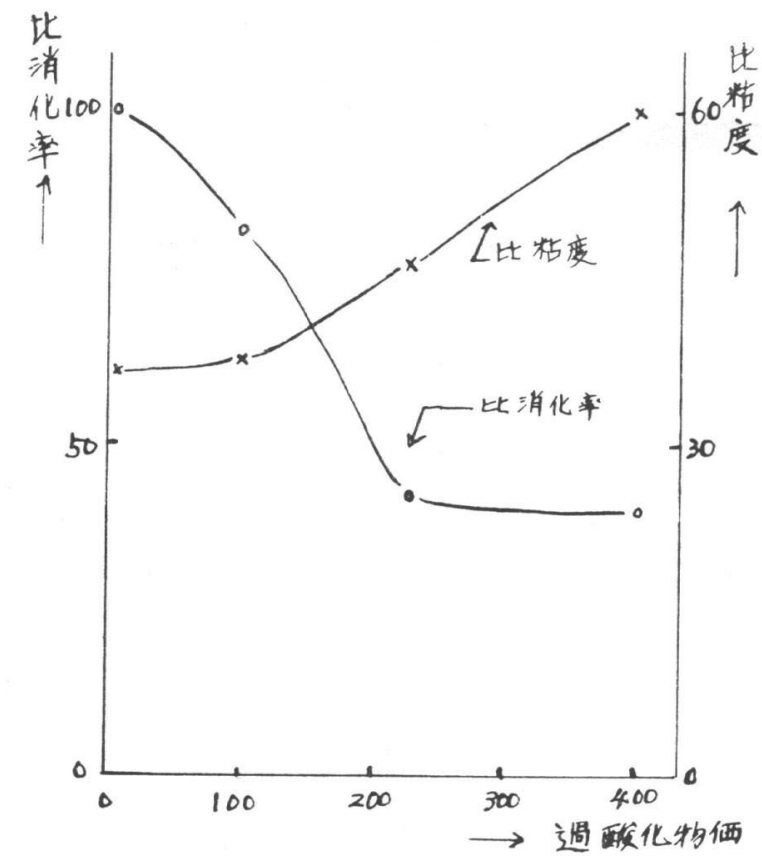

今以上の結果をそれぞれの比消化率学以って示 せば，第 5 表の通りである。

これらの関係をグラフに示せば第 3 図の如くだ ある。な打比粘度と分解度との関係を第 3 図に 示す。図で明らかなように粘度の上昇は緩やかで あるにもかかわらず，分解度注急激に下り，低值 を示している。すなわち過酸化物価の上昇による 分解度低下の影響と相伴うために, 少許の比粘度 の上昇が大きな分解度の低下を招来する形となる のであって, ‘過酸化物価の相関の方が強いことを 示すものと考えられる。

(5) 要約

素材としての過酸化物価 0.42 の生大豆油を用 い, これを通気しつつ $80^{\circ} \sim 90^{\circ} \mathrm{C}$ に加熱保持し, 過酸化物価約 $100,200,400$ の試料油を作り，過酸 化物価と, 比消化率との関係を調べ,なお他の油性 との関係も検討した。

1）過酸化物価約 200 までの上昇は著しく比消化率を低下させるがそれ以上約 400 までっても200のそれと 同程度の比消化率を示す。

2) 本実験における試料油の過酸化物価以外の油性の変化は小さい。比粘度は多少の上昇を示しているが過 酸化物価のそれに比し比消化率に影響するところは少ないと思われる。

過酸化物価が高くなるといわわる毒性が現われることはすでに知られているが2314)，午の消化に及汸す影響 が知られた。

実際に, 油を用いた調理を行なう場合, 高温の油をとのまま放置することが多く,この時に油が変敗して過 酸化物価が高くなる。このような油は, 食用しても, 我ヶの体に吸収される量が少ないわけである。 
（III） 高過酸化物価油の再加熱とその比消化率の変化

油の過酸化物価は, 油を再加熱すると低下する。この油に対する lipase による人工分解態度它追求して, 過酸化物価と比消化率の関係を知るに資した。

(1) 実験用素材：前実験で得た過酸化物価約 400 の油を用いた（これをA油と称する）。

(2) 試料油の調製

$\mathrm{A}$ 油に種々なる段階の加熱を行ない，以下(B)，(C)，…(N)，13種の再加熱油試料を得た。

(3) 実験種類

イ）14試料につき過酸化物価を測定し，これを参考として14試料中から(A)，(B)，(C)，(D)，(E)，( F)，(G)，(H)， (J)，の9 試料を抽出し，口）油性と八）人工分解度を測定した。油性測定方法および人工分解条件・方法は 前述の通りである。

(4) 結果と考察

イ）(A) (N)14試料の過酸化物価

測定の結果を第 6 表に掲げる。

再加熱して $180^{\circ} \mathrm{C}$ に達するまでの間に過酸 化物価が如何に変化（低下）するかを見る。 $100^{\circ} \mathrm{C}$ までの加熱では過酸化物価に殆えど変 動が認められない。 $160^{\circ} \mathrm{C}$ 亿達して（E油） 漸く過酸化物価の低下が明かになり， $160^{\circ} \mathrm{C}$ から $180^{\circ} \mathrm{C}$ 至る間に，激しく低下して（F 油), A 油 (過酸化物価400) の1/3となる。次 に $180^{\circ} \mathrm{C}$ に達した油（F油） 5 分閒 $180^{\circ} \mathrm{C}$ に保つときは, A油の ${ }^{1 / 11}$ 以下, $\mathrm{F}$ 油の ${ }^{1} /{ }_{4}$ の 過酸化物価に極端に低下する。 $180^{\circ} \mathrm{C}$ に 10 分間保つ（H油）ときはさらに低下するが, $180^{\circ} \mathrm{C}$ に30分， 60 分，さらにそれ以上の時間持続加熱しても，過酸化物価は10〜14に止り，最早これ以上は低 下しないものの如くである。

口) 試料油の油性

第 7 表 試 料 油 $の$ 油 性

\begin{tabular}{|c|c|c|c|c|c|c|c|c|}
\hline 試料油 & 加 熱 温 度 & 加熱持続時間 & 過酸化物価 & 酸 & 屈 & 折 率 & 比 & 粘 \\
\hline A & 0 & 0分 & 399.60 & 0.648 & & 1. 4740 & & 59.5 \\
\hline B & $50^{\circ} \mathrm{C}$ & 0 & 394.42 & 0.501 & & 14739 & & 67.9 \\
\hline $\mathrm{C}$ & $60^{\circ} \mathrm{C}$ & 0 & 393.23 & 0.501 & & 1. 4740 & & 62.5 \\
\hline $\mathrm{D}$ & $100^{\circ} \mathrm{C}$ & 0 & 384.49 & 0.491 & & 1. 4741 & & 63.4 \\
\hline $\mathrm{E}$ & $160^{\circ} \mathrm{C}$ & 0 & 310.51 & 0.669 & & 1.4736 & & 65.8 \\
\hline $\mathrm{F}$ & $180^{\circ} \mathrm{C}$ & 0 & 139.02 & 0.886 & & 1.4740 & & 82.0 \\
\hline G & $180^{\circ} \mathrm{C}$ & 5 & 35.15 & 0.926 & & 1. 4742 & & 92.0 \\
\hline $\mathrm{H}$ & $180^{\circ} \mathrm{C}$ & 10 & 22.54 & 0.926 & & 1. 4741 & & 81.1 \\
\hline $\mathrm{J}$ & $180^{\circ} \mathrm{C}$ & 60 & 14.68 & 0.784 & & 1. 4741 & & 84.2 \\
\hline
\end{tabular}

第 6 表 再加熱度と過酸化物価

\begin{tabular}{|c|c|c|c|}
\hline 試料油 & 加熱温度 & $180^{\circ} \mathrm{C}$ 持続時間 & 過 酸 化 物 価 \\
\hline $\mathrm{A}$ & 0 & 0 & 399.60 \\
$\mathrm{~B}$ & $50^{\circ} \mathrm{C}$ & 0 & 394.42 \\
$\mathrm{C}$ & $60^{\circ} \mathrm{C}$ & 0 & 393.23 \\
$\mathrm{D}$ & $100^{\circ} \mathrm{C}$ & 0 & 384.49 \\
$\mathrm{E}$ & $160^{\circ} \mathrm{C}$ & 0 & 310.51 \\
$\mathrm{~F}$ & $180^{\circ} \mathrm{C}$ & 0 & 139.02 \\
$\mathrm{G}$ & $180^{\circ} \mathrm{C}$ & 5 & 35.15 \\
$\mathrm{H}$ & $180^{\circ} \mathrm{C}$ & 10 & 22.54 \\
$\mathrm{I}$ & $180^{\circ} \mathrm{C}$ & 30 & 16.00 \\
$\mathrm{~J}$ & $180^{\circ} \mathrm{C}$ & 60 & 14.68 \\
$\mathrm{~K}$ & $180^{\circ} \mathrm{C}$ & 120 & 12.36 \\
$\mathrm{~L}$ & $180^{\circ} \mathrm{C}$ & 240 & 14.64 \\
$\mathrm{M}$ & $180^{\circ} \mathrm{C}$ & 480 & 11.93 \\
$\mathrm{~N}$ & $180^{\circ} \mathrm{C}$ & 600 & 9.43 \\
\hline
\end{tabular}


以上の $(\mathrm{A}) \sim(\mathrm{N})$ の試料油中から, 過酸化物価の動きを参照して (A), (B), (C), (D), (E), (F), (G), (H), (J), の9 試 料を抽出し，その油性を測定した。結果は第 7 表に示す通りである。

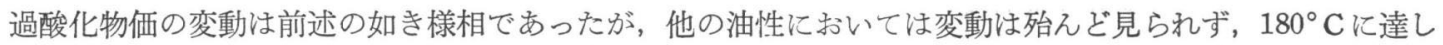
て酸価と比粘度に僅かに上昇の傾向を認めるのみである。

第 8 表 再加熱高過酸化物価油の分解度

\begin{tabular}{|c|c|c|c|c|}
\hline 試料油 & 加熱温度 & 加熱持続時間 & 分解度\% & 比消化率 \\
\hline 生大豆油 & 0 & 0 & 24.6 & 100 \\
$\mathrm{~A}$ & 0 & 0 & 10.4 & 42.3 \\
$\mathrm{~B}$ & $50^{\circ} \mathrm{C}$ & 0 & 10.8 & 44.0 \\
$\mathrm{C}$ & $60^{\circ} \mathrm{C}$ & 0 & 10.3 & 41.9 \\
$\mathrm{D}$ & $100^{\circ} \mathrm{C}$ & 0 & 10.4 & 42.3 \\
$\mathrm{E}$ & $160^{\circ} \mathrm{C}$ & 0 & 10.4 & 42.3 \\
$\mathrm{~F}$ & $180^{\circ} \mathrm{C}$ & 0 & 10.7 & 43.5 \\
$\mathrm{G}$ & $180^{\circ} \mathrm{C}$ & 5 & 10.9 & 44.4 \\
$\mathrm{H}$ & $180^{\circ} \mathrm{C}$ & 10 & 12.0 & 48.8 \\
$\mathrm{~J}$ & $180^{\circ} \mathrm{C}$ & 60 & 12.1 & 49.2 \\
\hline
\end{tabular}

比粘度）の変化をまとめて，第 4 困に示す。

過酸化物価の変動と比消化率 の間には, 直接の相関は見られ ない。一旦高過酸化物価を示し た油の比消化率は, 過酸化物価 が再加熱により低下しても, 変 化を示さない。このことは，高 過酸化物価油において lipaseの 分解を妨害するものが, 過酸化 物であるとすれば, 過酸化物が 再加熱により分解した残基部分 に，この妨害性があることを暗

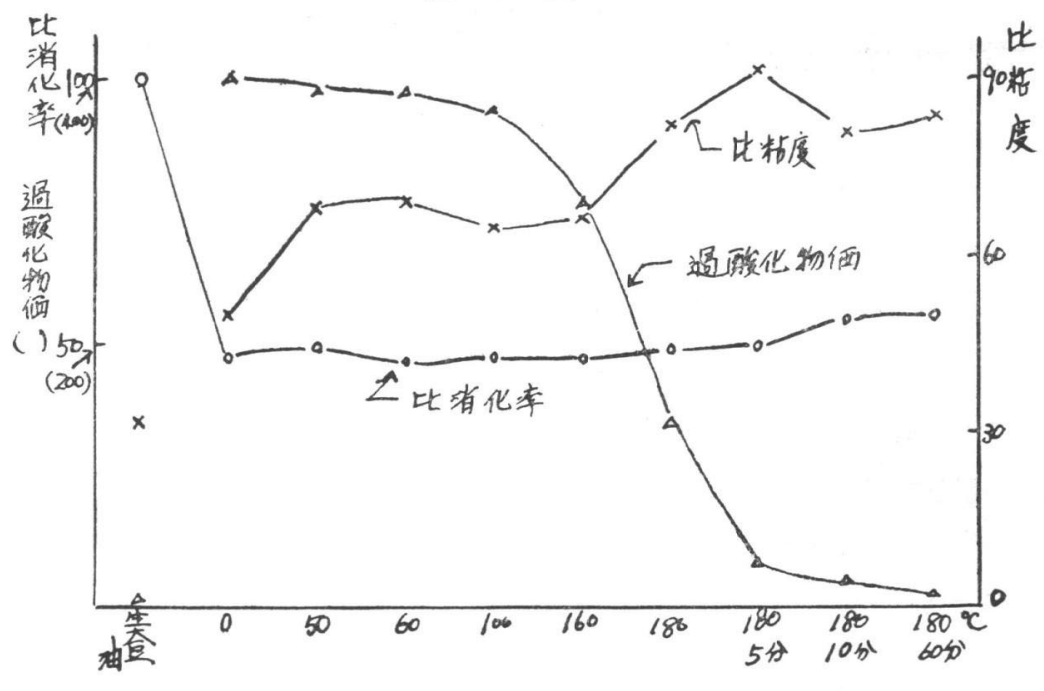
示し，またこの分解妨害物は，過酸化物を生成すると同一の生成条件下で，同時に生成されたものということ も考えられる。そしていずれにしてもこの妨害性は, $180^{\circ} \mathrm{C} 1$ 時間加熱によっても破壞されないこと示して いる。

(5) 要 約

1）油の過酸化物価は再加熱により低下する。

2) 過酸化物価は低温加熱 $\left(100^{\circ} \mathrm{C}\right)$ では変化は少ないが， $180^{\circ} \mathrm{C} に$ 持続加熱すると，初めの少時に急激に 殆んど最低まで低下し，その後は加熱時間を延長しても殆んど変化は認められない。

3）また再加熱して過酸化物価が低下してもその油の酸価は殆えど変化がない。

4）同じく屈折率においても変化は認められなかった。

5）比粘度は多少上昇した。 
6) これらの再加熱油の比消化率の変化とそれぞれの油の過酸化物価の低下との間に, 直接の相関は見られ ない。すなわち一旦分解度の低下した高過酸化物価油は, 再加熱して過酸化物価が低下しても, 分解度の上昇 は認められない。

7）高過酸化物価油の lipase 分解妨害性は過酸化物の加熱分解残基の持つ性質かも知れない。また過酸化 物生成と同一条件で同時に生成した他の何ものかであるかも知れない。

8）高過酸化物価油の lipase 分解妨害性は $180^{\circ} \mathrm{C}$ 加熱 1 時間で損なわれない。

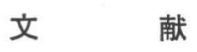

1）赤堀：醰素研究法, 2 巻, 4 (1956)

2) 日本油脂化学協会編：油脂分析試験法

3）松尾：生化学, $29,769,773,807,813,885$ (1958)

4) 秋谷: 栄養と食糧, 14, 71 (1961)

5）松尾：栄養と食糧, 15, 69 (1962)

（受付：昭和 42 年 6 月 30 日）

抄録

食餌と人間の赤血球燐脂質組成 The Effect of Phospholipid Composition of the Red Blood Cells of Man. J. G. Mill, A. Kuksis, J. M. R. Beveridge: J. Am. Oil Chem. Soc., 42, 137 (1965)

20 名の成人男子に普通食, $40 \%$ ( Cal) バタ一食, $40 \%$ Corn Oil 食を16日与光, 赤血球 (R. B. C) の総燐脂質, その fraction および各'fraction の脂 酸組成を測った。総燐脂質および各 fraction は各 群とも大差なく, 燐脂質は $12.6 \mathrm{mg} / 100 \mathrm{ml}$ - fraction 別では Lecithin はその34\%, Sphingomyelin (S. M) $25 \%$, Phosphatidyl ethanol amine (P.E) $25 \%$, Phosphatidyl (P.S. ) 16\%であった。総燐脂 質の $14 \%$ Plasmogen 形態で, その内P. E. は 36 \%,P.S. $6 \%$, Lecithin は 4 \%を占めていた。脂酸 組成について P.E., P. S., Lecithinの saturated/ unsaturated ratioは略 $1 ： 1$ あったが sphingomyelin は $3: 1$ で不飽和脂酸が多く, その $1 / 3$ 以上 が Behenic, Lignoceric, Nervonic の各酸を構成
する $\mathrm{C}_{20}$ 以上のものであった。

Corn Oil群はバター群よりもLecithin Fraction にリノール酸が多く, Oleic Acid が少なかったが アラキドン酸量は変らなかった。 P. S . にもリノー ル酸が多かった。

要するに総燐脂質ではあまり変化がみられなかっ たが, Lecithin Fractionに限って迅速な脂酸組 成の exchange がみられた。また不飽和脂酸だけが 変化し, そのリノール酸成分は増えると同時に他の 既存脂酸(オレイン酸)が減ったので総飽和脂酸は量 的に変わらなかった。このことより血漿とR. B. C. 燐脂質之の間に脂酸の specific rapid exchangeが 行なわれ, 燐脂質の種類, 脂酸の type およびその 特異性などの因子が考党られる。また R. B.C 燐脂 質脂酸が食餌より受ける影響として, その type 並 びに程度には限界があるようで, 食餌, 血漿, 脂肪 組織の脂酸以外にある因子も R. B. C 燐脂質脂酸組 成に支配的な役割を演じているであろう。(鈴木秀) 